Link article (Style APA): Vlasova, O. I., \& Shevchuk, V. V. (2021). Integral personal and interpersonal characteristics of parents of children with complex developmental disorders. Insight: the psychological dimensions of society, 6, 110-124. DOI: 10.32999/2663-970X/2021-6-8

Link article (Style DSTU 8302: 2015): Vlasova, O. I., Shevchuk, V. V. Integral personal and interpersonal characteristics of parents of children with complex developmental disorders. Insight: the psychological dimensions of society, 2021, 6, 110-124. DOI: 10.32999/2663-970X/2021-6-8

\title{
Integral personal and interpersonal characteristics of parents of children with complex developmental disorders
}

\author{
Інтегральні особистісні та міжособистісні характеристики \\ батьків дітей з комплексними порушеннями розвитку
}

Received: September 15, 2021

\section{Vlasova Olena Ivanivna}

Doctor of Psychological Sciences, Professor Department of Developmental Psychology Taras Shevchenko National University of Kyiv, Ukraine vlalit@ukr.net

https://orcid.org/0000-0002-9894-0038

Shevchuk Victoriya Valentynivna

Candidate of Psychological Sciences, Assistant Professor

Department of Psychology

Poltava V. G. Korolenko National

Pedagogical University

viktoriiashevchukpnpu@gmail.com

https://orcid.org/0000-0001-7101-7617

\section{Abstract}

The purpose of the research is to study integral personal and interpersonal characteristics of parents bringing up children with complex developmental disorders. The article is based on the following psychodiagnostics methods: Parental Attitude Questionnaire (A. Varga \& V. Stolin); Family Relationship Analysis (E. Eidemiller, V. Yustytskis); PARI (Parental Attitude Research Instrument) (E. Schaefer \& Bell); Freiburg Personality Inventory (FPI) for studying personal characteristics; N. Kurhanska \& T.A. Nemchyn method to assess mental activation, interest, emotional tonus, tension, and comfort; "The semantic differential" (Ch.
Accepted: November 11, 2021

\author{
Власова Олена Іванівна \\ доктор психологічних наук, професор \\ кафедра психології розвитку \\ Київський національний університет \\ імені Тараса Шевченка, Україна \\ vlalit@ukr.net \\ https://orcid.org/0000-0002-9894-0038 \\ Шевчук Вікторія Валентинівна \\ кандидат психологічних наук, доцент \\ кафедра психології \\ Полтавський національний педагогічний \\ університет \\ імені В. Г. Короленка, Україна \\ viktoriiashevchukpnpu@gmail.com \\ https://orcid.org/0000-0001-7101-7617
}

\section{Анотація}

Метою статті є дослідження інтегральних особистісних та міжособистісних характеристик батьків, які виховують дітей з комплексними порушеннями розвитку. Використано такі психодіагностичні методики: опитувальники для вимірювання параметрів батьківського ставлення (А. Варга, В. Столін); для аналізування сімейних взаємин (Е. Ейдеміллер, В. Юстицкіс); тест-опитувальник PARI (E. Шефер, Р. Белл) для вивчення батьківських настановлень; Фрайбурзький багатофакторний особистісний опитувальник (FPI) для дослідження особистісних характеристик; методику 


\section{Integral personal and interpersonal characteristics of parents of children with complex developmental disorders}

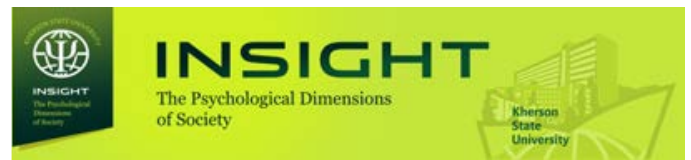

Osgood) for quantitative and qualitative value indexing; V. Kahan \& I. Zhuravlova Inventory for Parental Attitudes to the Child's Disease; "Sentence Completion Test." (J. Sacks \& L. Sidney). Factorization based on principal component analysis (PCA) followed by Varimax rotation of psychological scales has made it possible to gain a model of personal and interpersonal characteristics of parents bringing up children with complex developmental disorders. Research results. It has been specified personal characteristics in the form of dominant-aggressive, psychasthenic, extraversive, sthenic-introversive personal dispositions, which together form a marital subsystem. The research has outlined indulgent, authoritarian, constructive, phobic-indulgent, liberal-anxious educational systems that comprise a child-parent subsystem in the factor model of personal and interpersonal characteristics of parents. Conclusions. It is stated that substantial nature and particularities of integral personal and interpersonal factors, which have been noticed in parents bringing up children with complex developmental disorders, are personal predicators of the effectiveness of their psychological follow-up.

Keywords: psychological follow-up, personal disposition, educational subsystem, interpersonal relations.

\section{Introduction}

The birth of a child with developmental disorders is severe trauma, and parents do not realize the consequences of the disease immediately. Many parents refuse to grasp and accept this fact because it requires courage and reorganization of their consciousness, attitude to the child, and new living conditions.

Children with multiple, i.e., complex, forms of dysontogenesis caused by a congenital deficiency or acquired organic lesions of sensory organs, locomotor apparatus, or central nervous system, are characterized by atypical development. M. Zhyhoreva and I. Levchenko interpret such developmental disorders as a combination of several primary impairments, each of which determines the nature and structure of the anomaly. All disorders are mutually reinforcing, and thus, the manifestation of such dysfunctions is more severe quantitatively and qualitatively compared with a set of individual disorders. (Levchenko, Zhyhoreva, 2016). The term "complex developmental disorders" fully defines the structure of dysontogenesis since both
Н. Курганської, Т.А. Немчин для оцінки психічної активації, інтересу, емоційного тонусу, напруги та комфортності; “Семантичний диференціал" (Ч. Осгуд) для кількісного та якісного індексування значень; опитувальник В. Кагана та I. Журавльової для діагностики ставлення батьків до хвороби дитини; методика "Незакінчені речення" (Дж. Сакс, Л. Сідней). Факторизація методом головних компонент з наступним варімакс-обертанням матриці психологічних шкал дала змогу отримати модель особистісних та міжособистісних характеристик батьків дітей $з$ комплексними порушеннями розвитку. Результати дослідження. 3'ясовано особистісні характеристики у вигляді домінантно-агресивної, психастенічної, екстравертованої, стенічно-інтровертованої особистісних диспозицій, що разом утворюють шлюбну підсистему. Встановлено потуральну, авторитарну, конструктивну, фобічно-поблажливу, ліберально-тривожну виховні системи, які утворюють дитячо-батьківську підсистему у факторній моделі особистісних i міжособистісних характеристик батьків. Висновки. Констатовано, що змістовний характер і особливості інтегральних особистісних і міжособистісних чинників, які були з'ясовані у досліджуваних батьків дітей 3 комплексними порушеннями розвитку, є особистісними предикторами ефективності їх психологічного супроводу.

Ключові слова: психологічний супровід, особистісна диспозиція, виховна підсистема, міжособистісні взаємини.

\section{Вступ}

Народження дитини 3 вадами розвитку $\epsilon$ тяжкою травмою, усвідомлення наслідків якої сприймається батьками не відразу. Багато батьків відмовляється зрозуміти та сприйняти цей факт, оскільки це потребує мужності та перебудови своєї свідомості, свого ставлення до дитини та до нових умов життя.

Для дітей зі складними множинними, тобто комплексними, формами дизонтогенезу внаслідок вродженої недостатності чи набутого органічного ураження сенсорних органів, опорно-рухового апарату або центральної нервової системи, є характерним атиповий розвиток. М. Жигорева та І. Левченко під такими вадами розвитку розуміють поєднання декількох первинних порушень, кожне з яких визначає характер і структуру аномалії. Усі порушення взаємопідсилюються, тому прояв 
primary and ensuing secondary impairments should be considered integrally and holistically (Hladkykh, 2014).

Family and social relationships deteriorate because of the birth of a child with various forms of dysontogenesis. The causes of disorders are related to the psychological characteristics of the child, emotional overload of family members due to prolonged stress. Researcher V. Tkachova (2014) characterizes the state of parents as a psychological and social impasse. Parents bringing up a child with psychophysiological disorders experience so-called parental stress, the stages and essence of which are thoroughly studied in psychology (Hodapp, 2007; Hintermair, Sarimski, 2017; Aleksandrova, Dermanova, 2019; Ivanova et al., 2017). Studies show that mothers of such children are more depressed, busier with children, and have great difficulties with the selfcontrol of negative emotions towards children than mothers of neurotypical children (Hodapp, Blacher, 2007). The neurotic state of mothers is characterized by neurotic depression, which over time undergoes alteration to the anxiety complex with a hysterical type of response to the life situation (Pevneva, 2019; Herasymenko, Skrypnikov, Isakov, 2019), and psychosocial maladaptation (Sedykh, Shevchuk, 2020). The dominant feelings of parents of children with developmental disorders are fear and guilt. The most pronounced ones are the following characteristics of emotional family relationships: emotional support, the ability to perceive the child's condition, the prevailing emotional background of interaction. Parents mostly pay excessive attention to the child, and they have a positive or adequate attitude towards children (Babatina, Shvestko, 2019). Domestic psychology lacks research on the impact of the nature and degree of pathology on parental attitudes towards children with complex developmental disorders. Therefore, it is essential to conduct comparative studies of parents who have children with different types of dysontogenesis (Shevchuk, 2021).

An increase in the number of children with mental and physical disabilities has been recently set - 1307 cases per 10.000 births; the number of F84 cases - autism spectrum disorders (ASD) - has increased (Simashkova et al., 2020). таких дисфункцій $є$ кількісно і якісно грубішим, порівняно $з$ простою сукупністю окремих порушень. (Левченко, Жигорева, 2016). Термін "комплексні порушення розвитку" повною мірою визначає структуру дизонтогенезу, оскільки і первинні, і спровоковані ними вторинні вади, доцільно розглядати цілісно, у комплексі (Гладких, 2014).

У результаті народження дитини 3 різними формами дизонтогенезу, стосунки у сім'ї та з соціумом спотворюються. Причини порушень пов'язані з психологічними особливостями дитини, 3 емоційним перевантаженням членів їі сім'ї у зв'язку з тривалим стресом. Дослідниця В. Ткачова (2014) характеризує стан батьків як психологічний та соціальний глухий кут. Батьки, які виховують дитину з психофізичними порушеннями, перебувають у ситуації так званого батьківського стресу, стадії та зміст якого досить повно вивчені у психології (Hodapp, 2007; Hintermair, Sarimski, 2017; Александрова, Дерманова, 2019; Іванова та ін., 2017). Дослідження показують, що матері таких дітей більше пригнічені, більше зайняті з дітьми і мають великі труднощі з самоконтролем негативних емоцій щодо дітей, ніж матері нормотипових дітей (Hodapp, Blacher, 2007). Для невротичного стану матерів характерною $\epsilon$ невротична депресія, яка з часом модифікується до комплексу тривоги з істеричним типом реагування на ситуацію життєдіяльності (Певнева, 2019; Герасименко, Скрипніков, Ісаков, 2019), та психосоціальна дезадаптація (Седих, Шевчук, 2020). Основними почуттями батьків дітей $з$ вадами розвитку є страх та провина. Найбільш вираженими $є$ такі характеристики емоційних стосунків у сім'ї: надання емоційної підтримки, здатність сприймати стан дитини, переважаючий емоційний фон взаємодії. Серед батьків переважає надмірна концентрація на дитині, в цілому у них позитивне або нормальне ставлення до дітей (Бабатіна, Швестко, 2019). У вітчизняній психології наявний дефіцит досліджень 3 проблеми впливу характеру та ступеня патології на батьківське ставлення до дітей $з$ комплексними порушеннями розвитку. Тому важливо проводити порівняльні дослідження батьків, які мають дітей з різним типом дизонтогенезу (Шевчук, 2021). 
Integral personal and interpersonal characteristics of parents of children with complex developmental disorders

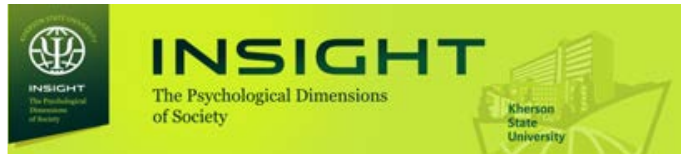

As of 2001, there were 154.3 thousand children with various forms of dysontogenesis in Ukraine, and in 2020 - 165 thousand, including 70 thousand girls and 95 thousand boys. The following developmental disorders dominate: congenital abnormalities -49.2 thousand, mental and behavioral disorders - 27.1 thousand, nervous system diseases - 25.5 thousand children (Senyk, 2020).

The purpose of the research is to study integral personal and interpersonal characteristics of parents raising children with complex developmental disorders.

\section{Methodology}

The study has involved 472 families, of which 152 have children with complex speech disorders in combination with mental development disorders, 136 raise children with musculoskeletal disorders in combination with mental incapacity, and 184 families with children without malformations.

Factor analysis of data has been performed to identify the characteristics of parents who raise children with complex developmental disorders and undergo a prolonged traumatic situation. Empirical data for factor analysis have been based on variables obtained from the results of such psychodiagnostic techniques as questionnaires for outlining parental feelings (A. Varga, V. Stolin); to analyze family relationships (E. Eidemiller, V. Yustytskis); PARI (E. Schaefer, R. Bell) to study parental attitudes; Freiburg Personality Inventory (FPI) to study personal characteristics; for assessing mental activation, interest, emotional tonus, tension, and comfort (N. Kurhanska \& T.A. Nemchyn method); for quantitative and qualitative value indexing ("Semantic differential" by Ch. Osgood); "Sentence Completion Test." (J. Sacks \& L. Sidney) to clarify parental attitudes towards themselves, their past, present, future, family life, and the child.

\section{Results and discussion}

Factor analysis of psychological scales assessed using the above questionnaires, PCA followed by Varimax normalized matrix allowed generating a factor model of personal and interpersonal characteristics of parents raising children with complex forms of dysontogenesis. Factor decision
Останнім часом виявлено зростання кількості дітей з порушеннями психофізичного розвитку - 1307 випадків на 10000 народжених; збільшилася кількість випадків F84 - розладів аутистичного спектру (РАC) (Симашкова та ін., 2020). Станом на 2001 рік дітей з різними формами дизонтогенезу в Україні було 154.3 тис., а вже у 2020 році - 165 тис., 3 них 70 тис. дівчаток і 95 тис. хлопчиків. Серед порушень розвитку лідируючі позиції займають вроджені аномалії - 49.2тис., розлади психіки та поведінки - 27.1 тис., хвороби центральної нервової системи у 25.5 тис. дітей (Сеник, 2020).

Мета. Дослідити інтегральні особистісні та міжособистісні характеристики батьків, які виховують дітей з комплексними порушеннями розвитку.

\section{Методологія}

У дослідженні взяло участь 472 сім'ї, з них 152 мають дітей зі складними мовленнєвими порушеннями у поєднанні 3 порушеннями інтелектуального розвитку, 136 виховують дітей з порушеннями опорно-рухового апарату в поєднанні з інтелектуальною недостатністю, та 184 сім'ї, які мають дітей без вад розвитку.

Здійснено факторний аналіз даних для виявлення особливостей батьків, які, виховуючи дітей 3 комплексними порушеннями розвитку, перебувають у пролонгованій психотравмувальній ситуації. Основою емпіричних даних для факторного аналізу стали змінні, отримані за результатами таких психодіагностичних методик, як опитувальники: для виділення батьківського ставлення (А. Варга, В. Столін); для аналізу сімейних взаємин (Е. Ейдеміллер, В. Юстицкіс); тест-опитувальник PARI (Е. Шефер, Р. Белл) для вивчення батьківських установок; Фрайбурзький багатофакторний особистісний опитувальник (FPI) для дослідження особистісних характеристик; методику Н. Курганської, Т. Немчин для оцінки психічної активації, інтересу, емоційного тонусу, напруги та комфортності; “Семантичний диференціал” (Ч. Осгуд) для кількісного та якісного індексування значень; опитувальник В. Кагана та І.П. Журавльової для діагностики ставлення батьків до хвороби дитини; для виявлення ставлення 
under $90.6 \%$ factorization (informative nature of factor $1-16.36 \%$, factor $2-14.64 \%$, factor 3 $11.31 \%$, factor $4-10.11 \%$, factor $5-9.67 \%$, factor $6-8.28 \%$, factor $7-7.68 \%$, factor $8-6.654 \%$, factor $9-5.90 \%$ ) has contributed to the semantic interpretation of the factors that comprise the factor model of personal and interpersonal characteristics of parents who raise children with complex developmental disorders (Table 1).

The first factor, which substantiates $16.36 \%$ of the variance of features, contains the following psychological scales with the largest factor weight: "reactive aggression" (.856), which indicates a desire for dominance and aggressive attitude of parents to their environment; "control" (.662) characterizes the tendency of parents to use authoritarian parenting methods; "masculinity / femininity" (.662) demonstrates the activity of mental performance mainly by male ("masculine") type; "neuroticism (.616) highlights a pronounced asthenic-neurotic syndrome with psychosomatic disorders; "excessive requirements - restrictions" (.530) is evidence of a significant number of requirements limiting the child's independence; "excessive requirements - responsibilities" (-.894) means that requirements for the child are far from contributing to the full development of personality but rather provoke his psychotrauma; "moral aspect " (-.759) proves a lack of family respect for ethical and moral principles; "expressiveness" $(-.756)$ renders the degree of openness to demonstrate own feelings in the family, and the negative value of this scale indicates the absence of such openness; "sociability" (-.657) characterizes the low level of social activity and the need for communication.

The informative generalization of the psychological scales of the first factor emphasizes its aggressive basis ("reactive anxiety" is .856), excessive requirements (restrictions), control, high neuroticism, strong manifestations of masculinity, a lack of communication, expressiveness, and moral and ethical issues. Summarizing the above, the first factor is characterized as "aggressive-dominant personal disposition".

The second factor, justifying 14.639\% of the variance of features, also reflects досліджуваних батьків до себе, свого минулого, сьогодення, майбутнього, сімейного життя та дитини методика "Незакінчені речення" (Дж. Сакс, Л. Сідней).

\section{Результати та дискусія}

Факторний аналіз психологічних шкал, виміряних за допомогою вищезазначених опитувальників, методом Principal Components iз наступним Varimax normalized матриці, дав змогу отримати факторну модель особистісних і міжособистісних характеристик батьків, які виховують дітей з комплексними формами дизонтогенезу. Факторне рішення при повноті факторизації $90.6 \%$, інформативності чинника $1-16.36 \%$, чинника $2-14.64 \%$, чинника $3-11.31 \%$, чинника $4-10.11 \%$, чинника 5 $9.67 \%$, чинника $6-8.28 \%$, чинника $7-7.68 \%$, чинника $8-6.654 \%$, чинника $9-5.90 \%$ ) сприяло змістовій інтерпретації чинників, що складають факторну модель особистісних i міжособистісних ознак батьків, які мають дітей з комплексними порушеннями розвитку (табл. 1).

До першого чинника, що пояснює $16.36 \%$ дисперсії ознак, із найбільшою факторною вагою увійшли такі психологічні шкали: "реактивна агресивність" (.856), яка свідчить про прагнення до домінування та агресивне ставлення батьків до свого оточення; “контроль” (.662) характеризує схильність батьків використовувати авторитарні методи виховання дитини; “маскулінність/ фемінність" (.662) характеризує активність психічної діяльності переважно за чоловічим (“маскулінним") типом; “невротичність" (.616) свідчить про виражений невротичний синдром астенічного типу з психосоматичними порушеннями; "надмірність вимог - заборон" (.530) є свідченням значної кількості обмежуючих самостійність дитини вимог; "надмірність вимог - обов'язків" (-.894) означає, що вимоги до дитини не лише не сприяють повноцінному розвитку її особистості, а й можуть провокувати її психотравматизацію; "моральний аспект" (-.759) свідчить про недостатній ступінь сімейної поваги до етичних та моральних принципів; “експресивність" (-.756) виражає міру відкритості демонструвати свої

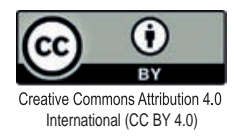




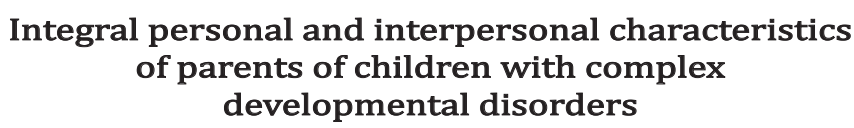

Table 1. Personal and interpersonal characteristics of parents raising children with complex developmental disorders Таблиця 1. Особистісні та міжособистісні характеристики батьків, які мають дітей з комплексними порушеннями розвитку

\begin{tabular}{|c|c|c|c|c|c|c|c|c|c|}
\hline \multirow{2}{*}{$\begin{array}{c}\text { Personal and interpersonal characteristics } \\
\text { Особистісна та міжособистісна } \\
\text { характеристика } \\
\end{array}$} & \multicolumn{9}{|c|}{$\begin{array}{c}\text { Factor } \\
\text { Чинник }\end{array}$} \\
\hline & 1 & 2 & 3 & 4 & 5 & 6 & 7 & 8 & 9 \\
\hline $\begin{array}{l}\text { Exorbitance of requirements (responsibilities) } \\
\text { Надмірність вимог (обов'язків) }\end{array}$ & -.894 & & & & & & & & \\
\hline $\begin{array}{l}\text { Reactive aggression } \\
\text { Реактивна агресивність }\end{array}$ & .856 & & & & & & & & \\
\hline $\begin{array}{l}\text { Moral aspect } \\
\text { Моральний аспект }\end{array}$ & -.759 & & & & & & & & \\
\hline $\begin{array}{l}\text { Expressiveness } \\
\text { Експресивність } \\
\end{array}$ & -.756 & & & & & & & & \\
\hline $\begin{array}{l}\text { Masculinity / Femininity } \\
\text { Маскулінність/Фемінність }\end{array}$ & .662 & & & & & & & & \\
\hline $\begin{array}{l}\text { Sociability } \\
\text { Комунікабельність }\end{array}$ & -.657 & & & & & & & & \\
\hline $\begin{array}{l}\text { Control } \\
\text { Контроль }\end{array}$ & .662 & & & & & & & & \\
\hline $\begin{array}{l}\text { Neuroticism } \\
\text { Невротичність }\end{array}$ & .616 & & & & & & & & \\
\hline $\begin{array}{l}\text { Exorbitance of requirements (restrictions) } \\
\text { Надмірність вимог (заборон) }\end{array}$ & .533 & & & & & & & & \\
\hline $\begin{array}{l}\text { Focus on rest } \\
\text { Орієнтація на відпочинок }\end{array}$ & & .942 & & & & & & & \\
\hline $\begin{array}{l}\text { Projection of own negative qualities } \\
\text { Проекція власних негативних якостей }\end{array}$ & & .785 & & & & & & & \\
\hline $\begin{array}{l}\text { Activity control } \\
\text { Контроль активності }\end{array}$ & & .764 & & & & & & & \\
\hline $\begin{array}{l}\text { Lack of responsibilities } \\
\text { Недостатність обов'язків }\end{array}$ & & -.703 & & & & & & & \\
\hline $\begin{array}{l}\text { Irritability } \\
\text { Роздратованість }\end{array}$ & & .550 & & & & & & & \\
\hline $\begin{array}{l}\text { Shyness } \\
\text { Сором'язливість }\end{array}$ & & & .906 & & & & & & \\
\hline $\begin{array}{l}\text { Underdeveloped parental feelings } \\
\text { Нерозвиненість батьківських почуттів }\end{array}$ & & & .835 & & & & & & \\
\hline $\begin{array}{l}\text { Tranquility } \\
\text { Урівноваженість }\end{array}$ & & & .753 & & & & & & \\
\hline $\begin{array}{l}\text { Permissiveness } \\
\text { Потурання }\end{array}$ & & & .745 & & & & & & \\
\hline $\begin{array}{l}\text { Cohesion } \\
\text { Згуртованість }\end{array}$ & & & .682 & & & & & & \\
\hline $\begin{array}{l}\text { Spontaneous aggression } \\
\text { Спонтанна агресія }\end{array}$ & & & .508 & & & & & & \\
\hline $\begin{array}{l}\text { Instable parenting } \\
\text { Нестійкість виховання }\end{array}$ & & & & .926 & & & & & \\
\hline $\begin{array}{l}\text { Conflict outreach } \\
\text { Винесення конфлікту }\end{array}$ & & & & .877 & & & & & \\
\hline $\begin{array}{l}\text { Mood swings } \\
\text { Емоційна лабільність }\end{array}$ & & & & .622 & & & & & \\
\hline
\end{tabular}


Continuation of table 1

Продовження таблиці 1

\begin{tabular}{|c|c|c|c|c|c|c|c|c|c|}
\hline \multirow{2}{*}{$\begin{array}{c}\text { Personal and interpersonal characteristics } \\
\text { Особистісна та міжособистісна } \\
\text { характеристика } \\
\end{array}$} & \multicolumn{9}{|c|}{$\begin{array}{l}\text { Factor } \\
\text { Чинник }\end{array}$} \\
\hline & 1 & 2 & 3 & 4 & 5 & 6 & 7 & 8 & 9 \\
\hline $\begin{array}{l}\text { Anxiety } \\
\text { Тривожність }\end{array}$ & & & & & .960 & & & & \\
\hline $\begin{array}{l}\text { Excessive sanctions } \\
\text { Надмірність санкцій }\end{array}$ & & & & & -.935 & & & & \\
\hline $\begin{array}{l}\text { Optimal emotional contact } \\
\text { Оптимальний емоційний контакт }\end{array}$ & & & & & -.614 & & & & \\
\hline $\begin{array}{l}\text { Comfort } \\
\text { Комфортність }\end{array}$ & & & & & -.506 & & & & \\
\hline $\begin{array}{l}\text { Phobia of losing the child } \\
\text { Фобія втрати дитини }\end{array}$ & & & & & & .900 & & & \\
\hline $\begin{array}{l}\text { Educational insecurity of parents } \\
\text { Виховна невпевненість батьків }\end{array}$ & & & & & & .770 & & & \\
\hline $\begin{array}{l}\text { Minimum sanctions } \\
\text { Мінімальність санкцій }\end{array}$ & & & & & & .702 & & & \\
\hline $\begin{array}{l}\text { Lack of requirements (restrictions) } \\
\text { Недостатність вимог(заборон) }\end{array}$ & & & & & & .696 & & & \\
\hline $\begin{array}{l}\text { Dissatisfaction } \\
\text { Незадоволеність }\end{array}$ & & & & & & & .969 & & \\
\hline $\begin{array}{l}\text { Tension } \\
\text { Напруга }\end{array}$ & & & & & & & -.723 & & \\
\hline $\begin{array}{l}\text { Extroversion / introversion } \\
\text { Екстравертованість/інтровертованість }\end{array}$ & & & & & & & -.636 & & \\
\hline $\begin{array}{l}\text { Interest } \\
\text { Iнтерес }\end{array}$ & & & & & & & .531 & & \\
\hline $\begin{array}{l}\text { Internality } \\
\text { Інтернальність }\end{array}$ & & & & & & & .505 & & \\
\hline $\begin{array}{l}\text { Emotional tonus } \\
\text { Емоційний тонус }\end{array}$ & & & & & & & & .893 & \\
\hline $\begin{array}{l}\text { Excessive emotional tension } \\
\text { Надмірна емоційна дистанція }\end{array}$ & & & & & & & & -834 & \\
\hline $\begin{array}{l}\text { Focus on achievements } \\
\text { Орієнтація на досягнення }\end{array}$ & & & & & & & & ,752 & \\
\hline $\begin{array}{l}\text { Intellectual and cultural orientation } \\
\text { Інтелектуально-культурна орієнтація }\end{array}$ & & & & & & & & .628 & \\
\hline $\begin{array}{l}\text { Mental activation } \\
\text { Психічна активація }\end{array}$ & & & & & & & & & .920 \\
\hline $\begin{array}{l}\text { Ignoring } \\
\text { Iгнорування }\end{array}$ & & & & & & & & & .656 \\
\hline $\begin{array}{l}\text { Nosognosia } \\
\text { Нозогнозія }\end{array}$ & & & & & & & & & .610 \\
\hline
\end{tabular}

the personal and interpersonal characteristics of parents. The following scales have the largest factor weight: "focus on rest" (.942); "projection of own negative qualities" (.785), a characteristic feature of which is the projection of unacceptable почуття у сім'ї, а негативне значення даної шкали свідчить про відсутність такої відкритості; “комунікабельність" (-.657) характеризує низький рівень проявів соціальної активності та потреби у спілкуванні. 
Integral personal and interpersonal characteristics of parents of children with complex developmental disorders

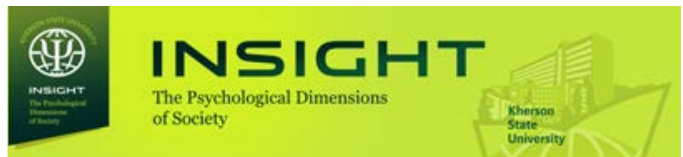

qualities on the child"; "activity control" (.764) characterizes the degree of the hierarchy of the family organization, the rigidity of family rules and procedures. Psychological scales of the second factor show that parents ignore the child's needs and have authoritarian parenting because they prefer to rest, project their negative qualities on the child, and control all spheres of his life. Summarizing the psychological variables of the second factor, it is regarded as “authoritarian educational disposition".

The third factor, which justifies 11.313\% of the variance of features, contains the following scales with the largest factor weight: "shyness" (.906), which indicates the presence of anxiety, insecurity, and awkwardness resulting in difficulties in establishing social contacts; "underdeveloped parental feelings (.835), which are manifested at the behavioral level in mild interests in the child; "tranquility" (.753) renders resistance to stress; "indulgence" (.745) expresses the parental attitude whereby they strive for maximum satisfaction of any needs of the child; "cohesion" (.682) expresses the degree of mutual assistance of parents raising children with complex developmental disorders; "spontaneous aggression" (.508), which indicates an increased level of psychopathization of an individual and his impulsive behavior. Psychologicalscales of thethird factor characterize the excessive indulgent style of raising a child combined with manifestations of shyness and tranquility of parents, who sometimes are characterized by spontaneous aggression. In general, this educational pattern confirms the personal disposition of parents towards the development of child's qualities of permissiveness. Summarizing the psychological variables of the third factor, it is characterized as "indulgent educational disposition".

The fourth factor, justifying 10.112\% of variance, reflects the personal characteristics of parents. This factor contains the following psychological scales with the largest factor weight: "instability of parenting style" (.926) indicates a tendency to spontaneous change of the parenting style; "conflict outreach in bringing up the child (.877) illustrates the dissatisfaction of spouses with each other's educational methods; "mood swings" (.622) conveys the variability of mood,
Змістовне узагальнення психологічних шкал першого чинника свідчить про його агресивну основу ("реактивна тривожність" складає .856), надмірність вимог (заборон), контролю, високу невротичність, сильні прояви маскулінності, недостатність комунікації, експресивність та морально-етичні проблеми. Узагальнюючи все вищезазначене, характеризуємо перший чинник як “агресивнодомінантну особистісну диспозицію".

Другий чинник, пояснюючи $14.639 \%$ дисперсії ознак, відображає також особистісні та міжособистісні характеристики батьків. 3 найбільшою факторною вагою увійшли такі шкали: "орієнтація на відпочинок" (.942); “проєкція власних небажаних якостей” (.785), характерною ознакоюякогоє проєкція неприйнятних для себе якостей на дитину; “контроль активності" (.764) характеризує міру ієрархічності сімейної організації, ригідності сімейних правил і процедур. Психологічні шкали другого чинника свідчать про ігнорування потреб дитини та прояви батьками авторитарного стилю у вихованні за рахунок того, що вони надають перевагу відпочинку, проєктують на дитину власні негативні якості та контролюють усі сфери ї̈ життєдіяльності. Змістово узагальнюючи психологічні змінні другого чинника характеризуємо його як “авторитарну виховну диспозицію".

Третій чинник, що пояснює $11.313 \%$ дисперсії ознак, з найбільшою факторною вагою містить у собі шкали “сором'язливості" (.906), яка свідчить про наявність тривожності, невпевненості та скутості, наслідком чого $є$ складнощі в соціальних контактах; "нерозвиненість батьківських почуттів" (.835), яка на поведінковому рівні відстежується у поверховості інтересів до дитини; "урівноваженість" (.753) відображає стійкість до стресу; "потурання" (.745) виражає батьківське ставлення, за якого вони прагнуть до максимального задоволення будь-яких потреб дитини; “згуртованість" (.682) виражає міру взаємодопомоги батьків, які виховують дітей з комплексними порушеннями розвитку; “спонтанна агресивність" (.508), яка свідчить про підвищений рівень психопатизації особистості та ії імпульсивну поведінку. Психологічні шкали третього чинника характеризують 
high level of sociability, fellowship in combination with increased excitability, irritability, and a lack of self-regulation; "general tension" (-.619), which is one of the forms of holistic psychological reaction of a person in extreme situations, is a personal dynamic phenomenon. Given the negative indicator of this scale, it is useful to emphasize that parents of children with complex developmental disorders have a weak general tension. Psychological scales of the fourth factor demonstrate the dominance of parents' lack of self-confidence and vulnerability. Summarizing the psychological variables of the fourth factor, it is characterized as "personal psychasthenic disposition".

The fifth factor explains $9.671 \%$ of the variance of features and consists of psychological scales, namely: "anxiety" (.960), which characterizes the specifics to experience emotional disturbance, anxiety that arises with uncertain threat to an expected event and is manifested in the prediction of its adverse outcome; "excessive sanctions" (-.935) characterizes the tendency of parents to avoid severe punishments (sanctions) and overreact to the child's minor disturbance of behavior; "optimal emotional contact" (-.614) indicates the absence of partnership between parents and children, ignoring their problems and interests, neglect of the child's activity; "comfort" (-.506) demonstrates the lack of parents' sense of complete physical, spiritual, and social well-being, satisfaction and acceptance of the environment.Summarizing thepsychological scales of the fifth factor, it is noted that it is a complex of a significant level of anxiety, zero sanctions, optimal emotional contact and comfort, and thus, is defined as "liberal- anxious educational disposition" of parents.

The sixth factor, justifying $8.276 \%$ of variance, renders the following psychological scales: "phobia of losing the child (.900) marks hypochondriac instructions of parents concerning the child and their exaggeration of his disorder; "parental education insecurity" (.770) is very closely related to the previous scale (parents have an excessive fear of making mistakes that keeps them meeting any needs and often the child's whims; "minimum sanctions" (.702) and "insufficient requirements (prohibitions)" (.696) illustrates the child's permissiveness. Psychological scales of the sixth factor combine sufficiently high надмірно поблажливий стиль виховання дитини, що поєднується з проявами сором'язливості та врівноваженості батьків, яким час від часу притаманна спонтанна агресія. Загалом цей виховний патерн свідчить про особистісну диспозицію батьків на виховання у дитини якостей вседозволеності. Узагальнюючи психологічні змінні третього чинника, характеризуємо його як "потуральну виховну диспозицію”.

Четверний чинник, пояснюючи 10.112\% дисперсії, відображає особистісні характеристики батьків. Із найбільшою факторною вагою до цього чинника увійшли психологічні шкали: "нестійкість стилю виховання" (.926), що свідчить про схильність до спонтанної зміни стилю виховання; “винесення конфлікту у процес виховання дитини” (.877), що ілюструє незадоволення членів подружжя виховними методами один одного; "емоційна лабільність" (.622) характеризує мінливість настрою, високий рівень комунікабельності, товариськості в комплексі 3 підвищеною збудливістю, дратівливістю та недостатньою саморегуляцією; “загальна напруженість" (-.619), яка $є$ однією з форм цілісної психологічної реакції людини в екстремальних ситуаціях, є особистісним динамічним феноменом. Враховуючи від'ємний полюс даної шкали, доцільно буде наголосити на тому, що батьки дітей з комплексними порушеннями розвитку мають слабку загальну напруженість. Психологічні шкали четвертого чинника свідчать про домінування у батьків тривожної невпевненості у собі та вразливості. Узагальнюючи психологічні змінні четвертого чинника, характеризуємо його як “особистісну пcuхастенічну диспозицію”.

П’ятий чинник пояснює $9.671 \%$ дисперсії ознак і містить у собі психологічні шкали: "тривожність” (.960), яка характеризує особливість переживати емоційне хвилювання, тривогу, що виникають у ситуаціях невизначеної загрози якійсь очікуваній події і виявляється у прогнозуванні несприятливого її завершення; "надмірність санкцій” (-.935) характеризує схильність батьків не застосувати суворі покарання (санкції) та надмірно реагувати на незначні порушення дитиною поведінки; “оптимальний емоційний контакт” (-.614) свідчить про 
Integral personal and interpersonal characteristics of parents of children with complex developmental disorders

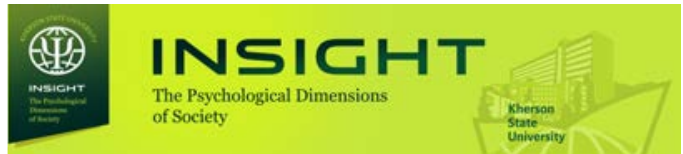

values of the hypochondriac and protection scales in relation to the child. Summarizing the psychological variables of the sixth factor, it is characterized as "phobic-indulgent educational disposition" of parents.

The seventh factor, justifying $7.678 \%$ of the variance of features, contains the following psychological scales characterizing the particularities of individual and interpersonal traits of parents: "internality" (.505) - high figures of this scale describe the external parental control of the child's disease - disease causes are regarded as something that does not depend on the parents, one that they cannot control and cannot manipulate; "tension" (-.723) - indicators characterize the relaxed attitude to the child's disease; "extraversion / introversion "(-.636) indicates difficulties in establishing contacts, giving preference to activities that are not related to communication, keeping a distance in relations, tendency for not interfering in anything and not imposing their point of view. The generalization of the characteristics of the psychological scales of the seventh factor indicates a significant level of introverted orientation with high levels of dissatisfaction, interest, and internality. Based on the above, it is characterized as "sthenicintroverted personal disposition".

The eighth factor, conveying $6.652 \%$ of variance, comprises the following psychological scales: "emotional tonus" (.893) means immersion in activity, interest, focus on the subject of activity; "orientation on achievements" (.752) indicates the high importance of achievements peculiar to various activities (education, work, etc.) in the family; "intellectual and cultural orientation" (.628) characterizes the degree of activity of family members in social, intellectual, cultural and political spheres; "excessive emotional distance" (-.834) points to the absence of irritability, strictness, excessive severity towards the child with complex disorders and optimal emotional contact with her. Psychological scales of the eighth factor mark a responsible attitude of parents to their responsibilities and the child's interests, hobbies, and needs. Summarizing the psychological variables of the eighth factor, it is characterized as "constructive educational parental disposition". відсутність партнерських стосунків між батьками та дітьми, ігноруванні їх проблем та інтересів, не підтримка активності дитини; “комфортність" (-.506) характеризує відсутність у батьків відчуття повного фізичного, духовного та соціального благополуччя, задоволення та прийняття оточення. Узагальнюючи психологічні шкали п'ятого чинника, відзначимо, що він $є$ комплексом значного рівня тривожності, відсутності санкцій, оптимального емоційного контакту та комфортності, тому визначаємо його як “ліберально-тривожну виховну диспозицію” батьків.

Шостий чинник, пояснюючи $8.276 \%$ дисперсії, відображає такі психологічні шкали: “фобія втрати дитини” (.900), що свідчить про іпохондричні настанови батьків щодо дитини та перебільшення ними уявлення про її ваду; “виховна невпевненість батьків" (.770) дуже тісно пов'язана з попередньою шкалою (батьки мають підвищений страх помилитися і це спонукає їх тривожно задовольнити будьякі потреби, а часто й забаганки дитини; "мінімальність санкцій" (.702) та "недостатність вимог (заборон)” (.696) ілюструє вседозволеність дитини. Психологічні шкали шостого чинника поєднують у собі досить високі значення іпохондричних та протекційних шкал у ставленні до дитини. Змістовно узагальнюючи психологічні змінні шостого чинника, характеризуємо його як “фобічно-поблажливу виховну диспозицію” батьків.

Сьомий чинник, пояснюючи 7.678 \% дисперсії ознак, містить такі психологічні шкали, що характеризують особливості індивідуальних та міжособистісних рис батьків: "інтернальність" (.505) - високі показники по цій шкалі описують екстернальний батьківський контроль хвороби дитини - причини хвороби сприймаються як щось, що не залежить від батьків, що вони не можуть контролювати і чим не можуть керувати; "напруга" (-.723) - характеризують ненапружене ставлення до захворювання дитини; "екстраверсія/інтроверсія" (-.636) - такі показники свідчать про складнощі в контактах, надання переваги видам діяльності, які непов'язані 3 комунікацією, тримають дистанцію у взаєминах, ні у що не втручаються і не нав'язують 
The ninth factor, justifying 5.904\% of the variance of features, includes psychological scales: "nosognosia" (.610) - high values of the scale demonstrate that parents exaggerate the severity of the child's disease, i.e., they are characterized by hypernosognosia; "ignoring the child (-.656) indicates a fairly high level of satisfaction of the child's needs, both material and spiritual. Psychological scales of the ninth factor combine hypernosognosia with openness to society, the craving for trusting relations. Summarizing the psychological variables of the ninth factor, it is characterized as "extroverted personal disposition".

Summing up the statistical factor analysis of personal and interpersonal characteristics of the parents raising children with complex developmental disorders, using questionnaires to study personal characteristics, emotional tonus, mental activation, tension, comfort, parental attitudes, the analysis of family relationships, it is distinguished a factor model of individual personal and interpersonal characteristics of parents. It consists of nine integral factors that convey the characteristics of parents under study in the structure of partnership (marital) and child-parent relationships in the family as a system (Fig. 1).

The theoretical analysis shows the presence of such inadequate models in the parent- child relationship: isolation, interconnectedness, silent co-presence, "influence and interinfluence", active interrelation. In addition, there is dominant, aggressive, friendly, and subordinate model of parenting (Makarenko et al., 2017), and psychoasthenic, ambivalent, dominantaggressive, extroverted, introverted-pedantic, passive-protective, indulgent, constructive, indulgent-indifferent disposition (Mushkevych, 2021). Parents raising children with complex developmental disorders often violate the style of family upbringing in the form of dominant hyper-protection and emotional neglect, and the presence of symbiotic relationships (Miliutina \& Ivashova, 2017).

\section{Conclusions}

The findings of the empirical study confirm that the substantive nature and features of integrated personal-individual and interpersonal factors of parents raising children with complex свою точку зору. Узагальнення характеристик психологічних шкал сьомого чинника свідчить про значний рівень інтровертованої орієнтації при високих показниках невдоволеності, інтересу та інтернальності. На підставі цього характеризуємо його як "стенічно-інтровертовану особистісну диспозицію".

Восьмий чинник, відображаючи 6.652 \% дисперсії, містить такі психологічні шкали: "емоційний тонус" (.893) означає занурення в діяльність, зацікавленість, спрямованість уваги на предмет діяльності; "орієнтація на досягнення" (.752) свідчить про високе значення важливості досягнень, яким наділяють різні види діяльності (навчання, праця тощо) у сім'ї; “інтелектуально-культурна орієнтація" (.628) характеризує міру активності членів сім'ї у соціальній, інтелектуальній, культурній та політичній сферах діяльності; “надмірна емоційна дистанція” (-.834) свідчить про відсутність у ставленні до дитини 3 комплексними порушеннями розвитку роздратованості, суворості, надмірної строгості та про оптимальний емоційний контакт з нею. Психологічні шкали восьмого чинника свідчать про відповідальне ставлення батьків до своїх обов'язків та до інтересів, захоплень і потреб дитини. Узагальнюючи психологічні змінні восьмого чинника, характеризуємо його як "конструктивну виховну батьківську диспозицію".

Дев'ятий чинник, пояснюючи 5.904 \% дисперсії ознак, містить психологічні шкали: “нозогнозія’ (.610) - високі показники даної шкали свідчать про перебільшення батьками важкості хвороби дитини, тобто їм властива гіпернозогнозія; “ігнорування дитини” (-.656) свідчить досить високий рівень задоволення потреб дитини як матеріальних, такі духовних. Психологічні шкали дев'ятого чинника поєднують у собі гіпернозогнозію з відкритістю соціуму, прагненням до довірливих взаємин. Узагальнюючи психологічні змінні дев'ятого чинника, характеризуємо його як "екстравертовану особистісну диспозицію”.

Підводячи підсумок під статистичним факторним аналізом особистісних і міжособистісних особливостей батьків, які виховують дітей $з$ комплексними порушеннями розвитку, за допомогою опитувальників дослідження особистісних характеристик, емоційного 


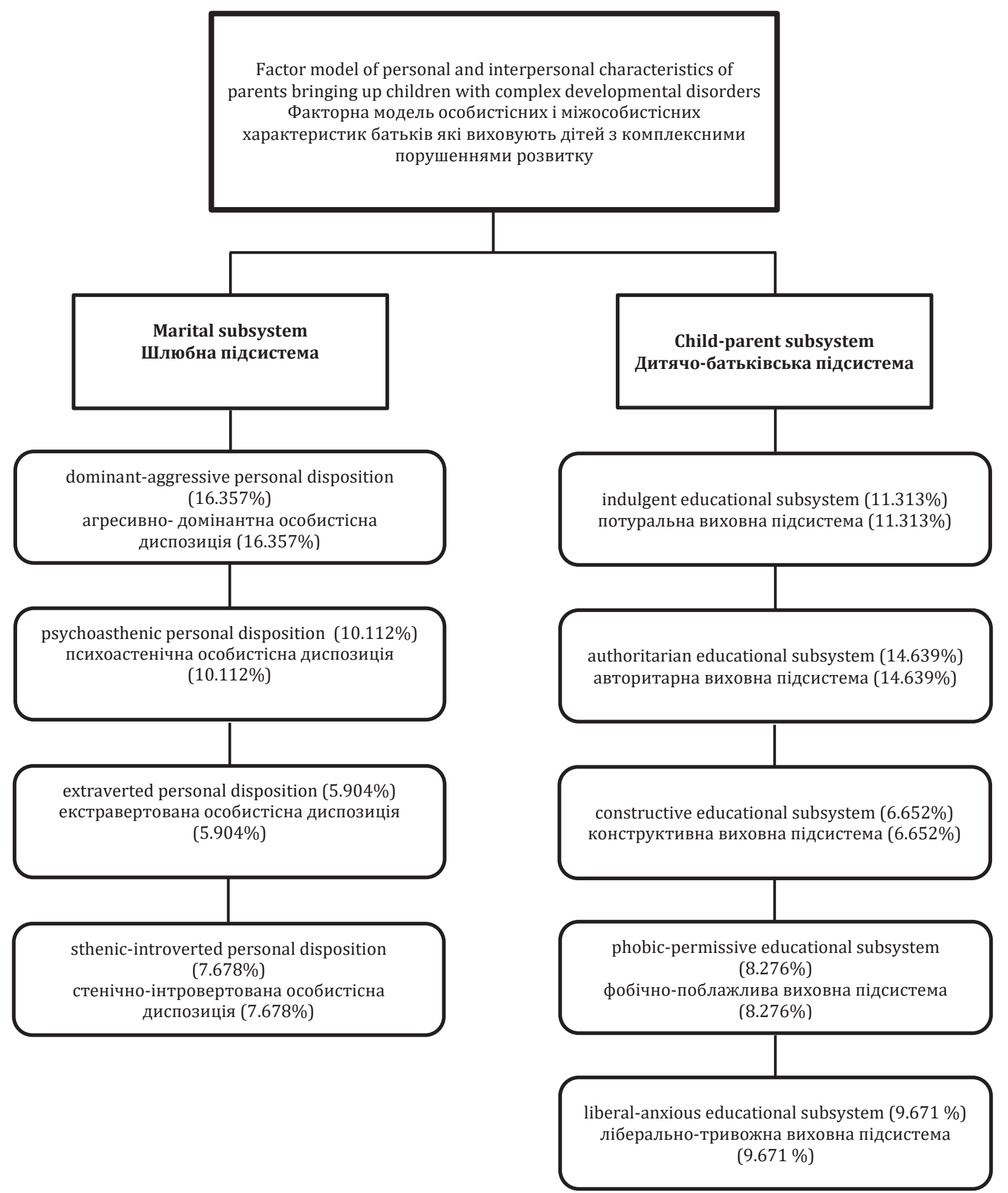

Fig. 1. Model of personal and interpersonal characteristics of parents bringing up children with complex developmental disorders

Рис. 1. Модель особистіснихта міжособистісниххарактеристик батьків, яківиховуютьдітей з комплексними порушеннями розвитку 
developmental disorders are predictors of their further optimal and efficient support in the form of psychological follow-up. This follow-up should be applied both to the individual and the whole family and the child with multiple complex forms of dysontogenesis, which are considered through the prism of diagnosis, psychoeducation, counseling, and psychotherapy of her parents.

Further study should deal with characteristics of the separated personal dispositions and educational subsystems of parents raising children with multiple complex forms of dysontogenesis, following gender, marital status, age differences, level of family functioning, and the presence of siblings in the family.

\section{References}

Aleksandrova, O. V., \& Dermanova, I. B. (2019). Otnoshenie vzroslyih rodstvennikov $\mathrm{k}$ tyazhelobolnomu rebenku i otsenka imi trudnoy zhiznennoy situatsii v svyazi s harakterom ego zabolevaniya. [The attitude of adult relatives towards a seriously ill child and their assessment of a difficult life situation in connection with the nature of his illness]. Psihologiya cheloveka $v$ obrazovanii - Human psychology in education, 1(7), 82-90 [in Russian].

Babatina S. I., Shvestko O. O. (2019). Empirychne doslidzhennia sotsialno-psykholohichnykh osoblyvostei batkivskoho stavlennia do ditei iz autyzmom. [Empirical study of socio-psychological features of parental attitudes towards children with autism] Insait: psykholohichni vymiry suspilstva: naukovyi zhurnal - Insight: the psychological dimensions of society, 2, 7-16 [in Ukrainian].

Herasymenko, L. O., Skrypnykov, A. M., \& Isakov, R. I. (2019). Diahnostyka psykhosotsialnoi dezadaptatsii u zhinok z depresyvnymy rozladamy [Diagnosis of psychosocial maladaptation in women with depressive disorders], Svit medytsyny ta biolohii-Theworldofmedicineand biology, 67,34-38 [in Ukrainian].

Gladkikh, N. V. (2014). Aktualni problemy navchannia ta vykhovannia ditei z kompleksnymy porushenniamy rozvytku $\mathrm{v}$ Ukraini. [Actual problems of education and upbringing of children with complex developmental disorders in Ukraine]. Naukovyi chasopys imeni M. P. Drahomanova. Seriia 19. Korektsiina pedahohika ta spetsialna psykholohiia - Scientific journal named after M.P Dragomanova. Correctional pedagogy and special psychology, Series, 26, 52-57 [in Ukrainian].

Zhigoreva, M. V. \& Levchenko, I. Y. (2016). Deti s kompleksnyimi narusheniyami razvitiya: Diagnostika i soprovozhdenie. [Children with complex тонусу, психічної активації, напруги, комфортності, батьківського ставлення, аналізу сімейних взаємовідносин, виокремлено факторну модель особистісно-індивідуальних і міжособистісних характеристик батьків. Вона складається 3 дев'яти інтегральних чинників, що відображають характеристики наших досліджуваних батьків у структурі партнерських (шлюбних) та дитячо-батьківських взаємин у сім'ї як системі (рис. 1).

Проведене теоретичне аналізування засвідчило наявність у дитячо-батьківських взаєминах таких неадекватних моделей: ізольованість, взаємопов'язаність, мовчазну співприсутність, “вплив і взаємовплив”, активний взаємозв'язок. Окрім того, виділяють домінуючу, агресивну, приязну та підлеглу модель виховання (Макаренко, Голубєва, Джугля, 2017), психоастенічну, амбівалентну, домінантно-агресивну, екстравертовану, інтровертовано-педантичну, пасивно-захисну, потуральну, конструктивну, поблажливо-байдужу диспозицію (Мушкевич, 2021). У батьків, які виховують дітей зі складними вадами розвитку, часто є порушення стилю сімейного виховання у вигляді домінуючої гіперпротекції та емоційного нехтування, і наявності симбіотичних зв'язків (Мілютіна, Івашова, 2017).

\section{Висновки}

Результати емпіричного дослідження засвідчили, що змістовний характер та особливості інтегральних особистісно-індивідуальних і міжособистісних чинників батьків дітей 3 комплексними порушеннями розвитку $€$ предикторами їх подальшої оптимальної та ефективної підтримки у вигляді психологічного супроводу. Цей супровід доцільно застосовувати як для окремої особистості, так і для сім'ї в цілому, та дитини зі складними комплексними формами дизонтогенезу, яку ми розглядаємо крізь призму діагностики, психоедукації, консультування та психотерапії її батьків.

Подальшого дослідження потребує характеристика виокремлених особистісних диспозицій та виховних підсистем у батьків, які виховують дітей зі складними комплексними формами дизонтогенезу, за гендерною 
Integral personal and interpersonal characteristics of parents of children with complex developmental disorders

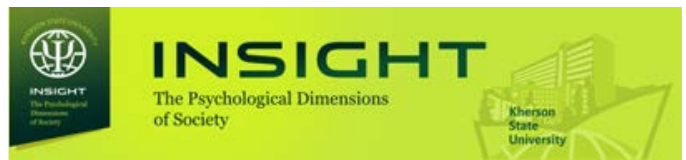

developmental disorders: Diagnosis and maintenance]. Moscow: National Book Center [in Russian]. $208 \mathrm{c}$.

Ivanova, V.S., Grebennikova, E. V., \& Shelekhov, I. L. (2017). Lichnostnyie osobennosti materey i roditelko-detskie otnosheniya $\mathrm{v}$ semyah, vospityivayuschih detey-invalidov $s$ detskim tserebralnyim paralichom. [Personal characteristics of mothers and parent-child relationships in families raising disabled children with cerebral palsy]. Nauchno-pedagogicheskoe obrazovanie - Scientific and pedagogical education, 2(16), 48-53 [in Russian].

Makarenko, O. M., Holubieva, M. O., Dzhuhlia, I. O. (2017). Psykholohichni osoblyvosti batkivskoho stavlennia do ditei iz osoblyvymy potrebamy. [Psychological features of parental attitude to children with special needs]. Mizhnarodnyi psykhiatrychnyi, psykhoterapevtychnyi ta psykhoanalitychnyi zhurnal - International Psychiatric, Psychotherapeutic and Psychoanalytic Journal, 1, 2(35-36), 107110 [in Ukrainian].

Miliutina, K. L., \& Ivashova, O. O. (2017). Vplyv batkivskoho stavlennia do ditei iz rozladamy autystychnoho spektru na perspektyvu inkliuzyvnoho navchannia. [The influence of parental attitudes towards children with autism spectrum disorders on the perspective of inclusive education]. Naukovyi visnyk Khersonskoho derzhavnoho universytetu. Seriia Psykholohichni nauky - Scientific Bulletin of Kherson State University. Psychological Sciences Series, 5, 98-102 [in Ukrainian].

Pevneva, A. N. (2019). Dinamika nevroticheskogo sostoyaniya materi rebenka $s$ tserebralnyim paralichom. [Dynamics of the neurotic state of the mother of a child with cerebral palsy]. Psykhyatryia, psykhoterapyia y klynycheskaia psykholohyia - Psihiatriya, psihoterapiya i klinicheskaya psihologiya, 10, 600-610 [in Russian].

Sedykh, K. V., \& Shevchuk, V. V. (2020). Osoblyvosti psykhosotsialnoi dezadaptatsii u zhinok, yaki vykhovuiut ditei obmezhenymy psykhofizychnymy mozhlyvostiamy. [Features of psychosocial maladaptation in women who raise children with limited psychophysical abilities]. Svit medytsyny ta biolohii - The world of medicine and biology, 2(72), 119-124 [in Ukrainian].

Symashkova, N. V., Yvanov, M. V., Makushkyn, E. V., \& Sharlai, Y. A. (2020). Skrining riska vozniknoveniya narusheniy psihicheskogo razvitiya detey rannego vozrasta [Screening of risk of mental disorders of young children]. Zhurnal nevrolohyy y psykhyatryy im. S. S. Korsakova - Journal of Neurology and Psychiatry. S.S. Korsakova, 11(120), 79-86 [in Russian].

Senyk, I.V. (Ed.). (2020). Sotsialnyi zakhyst naselennia Ukrainy u 2019 rotsi. Statystychnyi zbirnyk. [Social protection of the population of Ukraine ознакою, за сімейним статусом, віковими відмінностями, рівнем сімейного функціонування та наявності у сім'ї сиблінгів.

\section{Список використаних джерел}

Александрова О. В., Дерманова И. Б. Отношение взрослых родственников к тяжелобольному ребенку и оценка ими трудной жизненной ситуации в связи с характером его заболевания. Психология человека в образовании. 2019. T. 1. № 7. C. 82-90.

Бабатіна С. І., Швестко О. О. Емпіричне дослідження соціально-психологічних особливостей батьківського ставлення до дітей із аутизмом. Інсайт: психологічні виміри суспільства. 2019. № 2. C. 7-16.

Герасименко Л. О., Скрипников А. М., Ісаков Р. І. Діагностика психосоціальної дезадаптації у жінок 3 депресивними розладами. Світ медицини та біології. 2019. №1 (67). С. 34-38.

Гладких Н. В. Актуальні проблеми навчання та виховання дітей з комплексними порушеннями розвитку в Україні. Науковий часопис імені М.П. Драгоманова. Серія 19. Корекційна педагогіка та спеціальна психологія. 2014. № 26. С. 52-57.

Жигорева М. В., Левченко И. Ю. Дети с комплексными нарушениями развития: Диагностика и сопровождение. М.: Национальный книжный центр, 2016. 208 с.

Иванова В. С., Гребенникова Е.В., Шелехов И. Л. Личностные особенности матерей и родителько-детские отношения в семьях, воспитывающих детей-инвалидов с детским церебральным параличом. Научно-педагогическое образование. 2017. № 2(16). С. 48-53.

Макаренко О. М., Голубєва М. О., Джугля І. О. Психологічні особливості батьківського ставлення до дітей із особливими потребами. Міжнародний психіатричний, психотерапевтичний та психоаналітичний журнал. 2017. № 1, 2 (35-36). С. 107-110.

Мілютіна К. Л., Івашова О. О. Вплив батьківського ставлення до дітей із розладами аутистичного спектру на перспективу інклюзивного навчання. Науковий вісник Херсонського державного університету. Серія Психологічні науки. 2017. Вип. 5. Том 1. С. 98-102.

Певнева А. Н. Динамика невротического состояния матери ребенка с церебральным параличом. Психиатрия, психотерапия и клиническая психология. 2019. Том. 10. № 4. С. 600-610.

Седих К. В., Шевчук В. В. Особливості психосоціальної дезадаптації у жінок, які виховують дітей обмеженими психофізичними можливостями. Світ медицини та біології. 2020, № 2(72), С. 119-124.

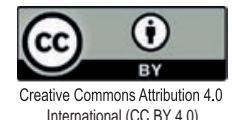




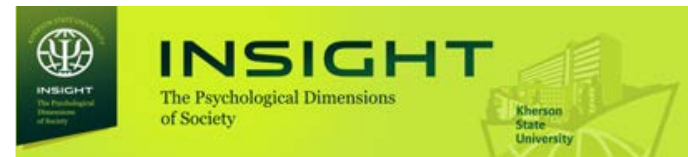

in 2019. Statistical collection]. Kyiv - Kyiv, 116 p. [in Ukrainian].

Tkacheva, V. V. (2014). Psykholoho-pedahohycheskoe soprovozhdenye semy rebenka s ohranychennыmy vozmozhnostiamy zdorovia. [Psychological and pedagogical support of the family of a child with disabilities], Izdatelskiy tsentr "Akademiya" - Moscow: Publishing Center "Academy", 272 p. [in Russian].

Shevchuk, V. V. (2021). Batkivske stavlennia do ditei z kompleksnymy porushenniamy rozvytku. [Parental attitude to children with complex developmental disorders]. The scientific heritage, 71, 61-65.

Hodapp, R. M. (2007). Families of persons with Down syndrome: New perspectives, findings, and research and service needs. Mental Retardation and Developmental Disabilities, 13, 279-287.

Hintermair, M., Sarimski, K. (2017). Sozial-emotionale Kompetenzen hörgeschädigter Kleinkinder. Ergebnisse aus einer Studie mit zwei neueren Fragebogeninventaren für das 2. und 3. Lebensjahr. Zeitschrift für Kinder- und Jugendpsychiatrie und Psychotherapie, 45(2), 128-140.

Mushkevych, V., Mushkevych, V., Fedorenko, R., \& Khlivna, O. (2021). Psychodiagnostic of individual perceptions of marriage and family relationships in modern youth. Youth Voice Journal this link is disabled, (SI 2), 66-76.

\section{Vlasova Olena, \\ Shevchuk Victoriya}

Ткачева В. В. Психолого-педагогическое сопровождение семьи ребенка с ограниченными возможностями здоровья. М.: Издательский центр “Академия”, 2014. 272 с.

Шевчук В. В. Батьківське ставлення до дітей з комплексними порушеннями розвитку. The scientific heritage. 2021. №71. C. 61-65.

Hodapp R. M. Families of persons with Down syndrome: Newperspectives, findings, and researchand service needs. Mental Retardation and Developmental Disabilities. 2007. №13. P. 279-287.

Симашкова Н. В., Иванов М. В., Макушкин Е. В., Шарлай И. А. Скрининг риска возникновения нарушений психического развития детей раннего возраста. Журнал неврологии и психиатрии имени С. С. Корсакова, 2020. № 11(120). С. 79-86.

Hintermair M., Sarimski K. Sozial-emotionale Kompetenzen hörgeschädigter Kleinkinder. Ergebnisse aus einer Studie mit zwei neueren Fragebogeninventaren für das 2. und 3. Lebensjahr. Zeitschrift für Kinder - und Jugendpsychiatrie und Psychotherapie. 2017. No. 45(2). P. 128-140.

Mushkevych V., Mushkevych V., Fedorenko R., \& Khlivna O. Psychodiagnostic of individual perceptions of marriage and family relationships in modern youth. Youth Voice Journal this link is disabled. 2021. (SI 2). P. 66-76. 